\title{
MUSICAL-AESTHETIC SPACE AS A FACTOR OF IMPLEMENTATION OF EDUCATIONAL-FUNCTIONAL MUSICAL FUNCTIONS
}

\section{Dobrovolska Rufina ${ }^{1}$}

DOI: https://doi.org/10.30525/978-9934-571-89-3_12

The professional training of future teachers of musical art is a complex system of pedagogical interaction between teachers and students, which aims to educate a broad-profile specialist who has the basics of professional activity: theoreticalmethodological, methodological, performing art studies, and creative. The teacher of the new Ukrainian school must be aware of the social and educational significance of educational functions of musical art and understand that their full and complete implementation today is possible only in the musical-aesthetic space of the educational institutions. Under the conditions of creating the musical-esthetic space of the school, musical art lessons find their logical continuation in extra-curricular musical activity of children, which provides the widespread use of new educational technologies.

The analysis of philosophical, psycho-pedagogical, and sociological literary sources shows the interest of theorists and practitioners in the concept of "space": a single educational space, educational space, cultural-educational space, space of childhood, each of which is a real-life phenomenon containing a certain list of elements, which characterize one or another sphere of human activity.

The idea of forming a cultural-educational space as a condition of education, education of pupils has an objective conditionality. The new tasks of the school, the variety of educational institutions, curricula, textbooks, socio-cultural processes associated with humanization as well as the deployment of information space are factors that must be taken into account when choosing ways to organize the educational process in a general education school. We believe that the culturaleducational space can not be clearly and unambiguously described, since it objectively has a high degree of uncertainty, may be diverse to ensure the free development and, as a consequence, the realization of the tasks of humanizing the educational process. The analysis of the theoretical baggage accumulated by scientific literature contributes to the comprehension of the essence of the category

\footnotetext{
${ }^{1}$ Vinnytsya State Pedagogical University, Ukraine
} 
"cultural-educational space". Consequently, cultural-educational space is a specially organized socio-cultural and pedagogical environment that stimulates the development and self-development of each individual included in it, the system of conditions for the personal and creative development of children and teachers, all subjects of the educational process, the environment for the development and upbringing of the individual [4, p. 409].

The musical-aesthetic space of a comprehensive school should logically fit into the cultural-educational space of an educational institution and be an integral part of it. In this regard, we note the significance of the concept of "musical-aesthetic space" for pedagogical science and the importance of its special study. On the basis of the analysis of scientific literature $[1 ; 2 ; 3]$ we have come to the conclusion that this concept, being interdisciplinary, may acquire a different meaning:

- from the point of view of philosophy, this is the space for the spiritual development of the personality of a student acquainted with musical art, and therefore perceives the results of the spiritual work of other people;

- from the standpoint of sociology, the musical-aesthetic space is considered as a subsystem of social space, in which the individual realizes special needs associated with musical creativity, aesthetic pleasure, in which the socialization of the individual, the assimilation of moral values is carried out;

- in accordance with the cultural approach, musical-aesthetic space is an environment of the functioning of musical culture as a subsystem of the whole artistic culture, with a complex of all its elements (institutions of culture and leisure, artistic creation, development of cultural products);

- from the point of view of psychology, musical-aesthetic space is a sphere of communication, a combination of artistic and aesthetic influences on the intellectualideological, emotional-volitional, needs-motivational, activity-behavioral sphere of the student's personality, which determines his individual and creative development;

- as a pedagogical phenomenon, musical-aesthetic space is part of the educationalcultural environment of a school with a significant educational potential.

Interpretation of the concept from the standpoint of musical pedagogy, as well as from the point of view of personality-oriented education is as follows: the musicalaesthetic space of the school - a component of the cultural-educational space of the school, which is the focus of the functioning of musical culture as part of the entire culture, the field of creative communication, the acquisition of creative experience of self-realization. In modern practice, the tendency towards the creation of a broad musical-aesthetic space as a part of the educational-cultural space of the school, which encompasses school, family, microdistrict, presents various forms of music existence, develops old and develops new traditions of musical communication.

Musical activity of children during the lesson and extra time in conditions of organization of musical-aesthetic space should be based on the following principles: use of new musical technologies; modeling of artistic and creative process; teaching music as an art; improvisation; study of music as a living art (D. Kabalevsky); continuity; sequences; systematic; single purposefulness; free choice of activity that coincides with the wishes and interests of schoolchildren; the optimal combination of 
forms (formal, extra-curricular, group, individual); positive emotional background (O. Rostovsky); the integration of different types of arts; stimulation of children's creativity [3, p. 183].

Under these conditions, it is important to create the readiness of the future teacher of musical art to create the musical-aesthetic space of the school as an environment in which it must perform musical and pedagogical activities.

At the same time, it should be noted that the professional training of future teachers of musical art in the context of forming their readiness for the creation of the musical-aesthetic space of the school has certain disadvantages: the lack of special discipline, which orientates students for the comprehensive mastering of the specifics of musical-professional activities; the lack of attention to the implementation of integration trends in learning, the accumulation of students knowledge of different disciplines without a system-oriented direction, which, in turn, exacerbates the contradiction between the need of schools in specialists who are able to implement in practice different forms of integration of musical education and education with the basics of various types of arts, and the lack of comprehensive preparation for such activities.

The musical-aesthetic space has a powerful educational potential, the importance of which grows in the professional training of the future teacher of musical art. The teacher-musician is called along with the function of the teacher and educator to serve as an educator, which becomes the foundation for the implementation of educational tasks in the music space of the school. The effectiveness of the musical-aesthetic space of the school depends on the formation of the readiness of the future teacher of musical art prior to its creation.

The realization of such educational functions of musical art as the formation of the musical culture of schoolchildren in the context of their general spiritual culture, the transfer of the spiritual experience of generations, concentrated in the musical arts, general musical development, the formation of aesthetic taste, musical outlook, can most effectively be realized only under conditions of musical-aesthetic space of institutions of general secondary education.

A modern teacher of musical art to create the musical-aesthetic space of institutions of general secondary education should have a sufficient level of development of the following qualities: appraisal (possession of a system of criteria for assessing the educational system, oneself, students); research (analysis of works of art, including musical, studying the experience of colleagues, students, analysis of their own work); forecasting (forecasting the results of interaction with students in musical and pedagogical activities); designing (related to the design of the entire educational and cognitive routes of the student, designed to ensure his entry into the system of musical-aesthetic space, planning the process of transfer of knowledge, the formation of skills of musical and creative development of students in the musicalaesthetic space of the school); constructive (associated with selection, compositional construction and conducting of music lessons, lessons, educational events); communicative (providing selection of speech means, optimal for solving the tasks of the lesson, using methods of interest of students, maintaining their attention 
throughout the lesson; expedient use of non-verbal communication techniques; possessing the ability to emotional brightness and orientation of emotions; ability to use rich intonation palette of speech); organizational (consisting of the ability to organize information in the process of studying, control and evaluation of its learning, organization of educational and cognitive musical and creative activity of students, interaction with objects of activity and knowledge, integration of information and transformation of it into personal knowledge, organizations of their own activities in such a way that it provides new achievements to the students).

One of the priority directions of modern professional training of the future teacher of music should be the formation of his readiness to create the musical-aesthetic space of the school. As a result of which there is the awareness of the need to achieve the integrity of the process of school music education along with profound acquisition of the foundations of music and pedagogical education.

\section{References:}

1. Galuziak V.M. (2013). Osvitnie seredovyshche yak faktor osobystisnoho rozvytku maibutnikh vchyteliv [Educational environment as a factor of personal development of future teachers] Proceedings of the Aktualni problemy pedahohichnoi teorii i praktyky: materialy mizhnarodnoi naukovoi konferentsii (Russia, Moscow, 2013) (eds. prof. O.I. Kirikova; prof. N.I. Smetanskogo), Voronezh: Voronezh State Pedagogical University, pp. 26-36.

2. Gordienko V.I. (2004). Orhanizatsiina kultura profesiino-osvitnoho seredovyshcha ta navchalnoho vuzivskoho protsesu [Organizational Culture of the Professional and Educational Environment and the educational university process]. Scientific notes of the National University "Kyiv-Mohyla Academy". Pedagogical, psychological sciences and social work, vol. 33, pp. 55-59.

3. Rostovsky O.Ya. (1997). Pedahohika muzyčnoho spryjmannja [Pedagogy of musical perception: Teaching. Manual]. Kyiv: IZMN. (in Ukrainian)

4. Holkovskaya I.L. (2018). Osoblyvosti sociokul'turnoho osvitn'oho prostoru jak čynnyka formuvannja social'noji kompetentnosti studentiv [Features of the socio-cultural educational space as a factor in the formation of social competence of students] Modern Information Technologies and Innovative Methods of Training in the Training of Specialists: Methodology, Theory, Experience, Problem, vol. 52, pp. 405-409. 